Nedrebø Bruvik, Å. (2018) Yrkesrelevant og meningsfull opplæring for elever med ulike utdanningsplaner i VG1 Scandinavian Journal of Vocations in development http://dx.doi.org/10.7577/sjvd.3070

Fagfellevurdert artikkel

(Peer reviewed article)

\title{
Yrkesrelevant og meningsfull opplæring for elever med ulike utdanningsplaner i VG1:
}

To eksempler på utvikling for yrkesrelevant og meningsfull undervisning.

Forfatter:

Åse Norunn Nedrebø Bruvik

OsloMet - storbyuniversitet

Fakultet for lærerutdanning og internasjonale studier, Institutt for yrkesfaglærerutdanning

abruvik@oslomet.no

Nøkkelord: relevans, meningsfull, yrkesretting, demokrati og elevinvolvering

Keywords: relevance, meaningful, occupation, democracy and students' involvement 


\section{Abstract}

The National guidelines for Norwegian VET emphasize that democracy, student involvement, career relevance, and curriculum coherence should be central elements of all VETprogrammes.

However, recent research suggests that, in practice, much of VET is too general and lacks focus on the students' individual needs, work interests and career plans. Several studies have found that students experience VET as lacking career relevance (Dahlback, Hansen, Haaland, \& Sylte, 2011; Hiim, 2013; Hovland, 2015).

As these studies show, there is a need to examine how VET programmes may be further developed and to identify teaching practices that support students' individual work interests and career plans.

This article addresses four action-research projects which attempted to develop such teaching practices.

Two of the projects were conducted in the Building and Construction programme and two were carried out in the Design, Arts and Crafts programme. In the projects, the teachers and students collaborated in developing teaching and learning practices that were tailored to the students specific learning needs.

The teachers planned, and assessed their own teaching based on feedback from student surveys conducted in their own classes.

The findings from the four projects show that students' involvement in the development of education and training is crucial to ensure that the education is experienced as relevant and meaningful to the individual students' interests and career plans. 


\section{Sammendrag}

Nasjonale retningslinjer er tydelige på at demokrati, medvirkning, relevans, samt helhet og sammenheng skal være sentralt i yrkesopplæringen. Nyere forskning viser at opplæringen er generell og lik for alle, uavhengig interesser eller yrkesplaner. Bredden i de yrkesfaglige utdanningsprogrammene blir presentert og tilbudt som en introduksjon til yrkene for alle elever, uavhengig om de har bestemt seg for yrke eller ikke (Dahlback, Hansen, Haaland, \& Sylte, 2011; Hiim, 2013; Hovland, 2015).

Som disse studiene viser, er det behov for å unders $\varnothing$ ke hvordan yrkesopplæringen kan videreutvikles og identifisere lærerpraksis som ivaretar elevenes individuelle interesser og yrkesplaner.

I artikkelen blir det presentert fire eksempler, to fra Bygg og anleggsfag og to fra Design og håndverk. Det empiriske materialet som ligger til grunn er innhentet gjennom, fokusgruppeintervjuer, tiltak i form av oppgavetekster, undervisningsplaner, dokumentasjon av elevarbeider, samt spørreundersøkelser. Tiltakene ble gjennomført i et aksjonsforskningsforløp i tett sammarbeid med forsker.

Funnene fra forskningsarbeidet viser at elevenes involvering i utvikling av opplæring og undervisning er avgjørende for å sikre at opplæringen oppleves relevant og meningsfull samt at den blir tilpasset den enkeltes interesser og/eller yrkesplan. 


\section{Introduksjon}

De siste årene har norsk yrkesopplæring vært gjennom store strukturelle endringer. Fra å være 112 yrkesfaglige studieretninger ble det redusert til 11 med innføring av Reform 94. Med Kunnskapsløftet (2006) er de yrkesfaglige utdanningsprogrammene ytterligere redusert til 9. Hvert utdanningsprogram har mange yrkesmuligheter og de fleste fører fram til fag eller svennebrev. Eksemplene i denne studien er fra utdanningsprogrammene Design og Håndverk (DH) og Bygg og anleggsteknikk (BA).

Nasjonale føringer er tydelige på at demokrati, medvirkning, relevans, samt helhet og sammenheng mellom felles programfag, fellesfag og yrkesfaglig fordypning skal prege yrkesopplæringen. Det skal være elevens utvikling av kompetanse, basert på elevens evne til å håndtere utfordringene, som skal stå i sentrum for opplæringen (St.meld. nr. 30, 2003-2004).

Til tross for at styringsdokumentene gir mulighet for yrkesopplæring, hvor elevens læringsbehov, knyttet til egen yrkesplan eller interesser skal ivaretas, viser forskning at elevene opplever opplæringen som lite relevant og meningsfull (Dahlback et al., 2011; Hiim, 2013; Hovland, 2015; Bødtker-Lund, Hansen, Haaland \& Vagle, 2017). Å gjennomføre en opplæring som er meningsfull og yrkesrelevant for elever som har bestemt seg for hvilke yrke de ønsker å utdanne seg til, samtidig ivareta elever som ikke har tatt et yrkesvalg, stiller høye krav til yrkesfaglærerens kunnskap og kompetanse innen programfagene og yrkene i de brede utdanningsprogrammene. Det kreves også en høy yrkesdidaktisk kompetanse (Bødtker-Lund et al., 2017).

\section{Prosjektets bakgrunn}

I artikkelen Relevans $i$ norsk yrkesopplaring, konkluderes det med at elevene har lite medbestemmelse og opplever undervisningen som lite relevant sett $\mathrm{i}$ lys av egne yrkesplaner/interesser (Bruvik \& Haaland, in press). Funn og spørsmålsstillinger som studiet løftet frem danner bakgrunnen for min motivasjon til å studere om det kan la seg gjøre å utvikle relevant og meningsfull undervisning sammen med yrkesfaglærere og yrkesfagelever i BA og DH, Vg1.

Problemstilling: Hvordan utvikle en yrkesrelevant og meningsfull undervisning for elever med ulike utdanningsplaner $i \mathrm{Vgl}$, BA og DH? 


\section{Utdyping av problemstillingen}

Artikkelen har fokus på utvikling av eksempler på relevant og meningsfull undervisning og læring. Eksemplene som presenteres er utviklet i samarbeid mellom lærere og elever i Vg1 Bygg og anleggteknikk og Design og håndverk.

\section{Fleksibilitet- muligheter- relevans}

Demokrati skal, i følge nasjonale føringer, være bærebjelken i norsk utdanning og elevene skal ha innflytelse på eget læringsarbeid på en slik måte at det oppleves relevant og meningsfylt. I følge den generelle læreplanen, som gjelder for hele grunnopplæringen ${ }^{1} \mathrm{i}$ Norge, skal skolen bidra til å utvikle et positivt menneskesyn og verdigrunnlag som verdsetter ulikheter og mangfold i felleskapet og skolen har som mål å utdanne gangs mennesker (Hansen \& Haaland, 2015; Den generelle læreplanen; St.Meld. nr. 30, 2003-2004). I yrkesutdanning betyr det blant annet å utdanne gode fagfolk som arbeider på en samfunnstjenlig måte og som ivaretar markedets behov for produkter og tjenester i takt med samfunnets utvikling (Hansen \& Haaland, 2015). I forskriften Prinsipper for opplaringen, står det at motiverte elever har lyst til å lære, holder ut lengre og at opplevd mestring styrker evnen til å holde ut i motgang (LK06). Videre står det at skolen og lærebedriften skal legge til rette for elevmedvirkning slik at elevene og lærlingene kan gjøre bevisste verdivalg, samt valg av utdanning og framtidig arbeid (Opplæringslova § 1-2, Forskrift kap. 22 og den generelle delen av læreplanverket). I følge St. meld.nr. 30 (2003-2004) Kultur for laering, som danner grunnlaget for kunnskapsløftet (LK06), hevdes det at et viktig grunnlag for læring og utvikling er at elever settes i situasjoner hvor de får relevante utfordringer for å utvikle sin kompetanse og fremtidens skole hevder blant annet at skoler som legger til rette for læringsprosesser som fører til forståelse, kan bidra til å styrke elevenes motivasjon og opplevelse av relevans i skolehverdagen (NOU 2015:8, 2015). I følge St. Meld. nr. 16 (20062007) har læreren ansvar for at elevens møte med skolen blir positiv, slik at det vekker faglig interesse, gir motivasjon og fører til læring, dette kjennetegnes ved variasjon i oppgaver, arbeidsmåter, læremidler og organisering av opplæringen (St.meld. nr. 16, 2006-2007, s. 76). Til tross for fleksibilitet og muligheter i politiske føringer er tilbakemeldingene fra arbeidslivet knyttet til mangel på faglig fordypning, samt lite fremtidsrettet kunnskap i 
forhold til bransjenes og samfunnets behov (Meld. St. 20, 2012-2013). Dette støttes av tidligere forskning (Dahlback et. al, 2011;Hiim, 2013; Hovland, 2015).

Problemstillingen artikkelen belyser har forankring i et kritisk, pragmatisk læringsperspektiv (Biesta, 2014; Dewey, 1966/1916; Hiim, 2013; Sylte, 2016). "Et pragmatisk kunnskapsbegrep innebærer at erfaring og språk blir ansett som prosess hvor begreper blir utviklet gjennom deltakelse i praktiske kontekster" (Hiim, 2013, s. 313). I et kritisk perspektiv på læring fremheves blant annet betydningen av demokratisk medvirkning i utviklingen av motivasjon, som i høy grad påvirker læringens kvalitet med hensyn til for eksempel; innholdets bruksmuligheter. I denne sammenheng kan det knyttes til elevenes yrkesplaner, fremtidsplaner eller interesser (Illeris, 2012). Keller hevder at skal læreren etablere, samt opprettholde relevansen i undervisningen, må man overbevise eleven om at innholdet har betydning for elevens fremtid (Keller, 2010, s. 97).

I prinsipper for opplæringen som er en del av læreplanverket i Kunnskapsløftet (LK06) står det at det er viktig at elevene har innflytelse på eget læringsarbeid for å utvikle motivasjon, engasjement og lærelyst. Begrepet medvirkning kan forstås i lys av rettigheter og medbestemmelser i styre og stell i for eksempel elevrådssystem, men i denne sammenheng forstås begrepet som innflytelse på og medbestemmelse i tolkning av kompetansemål i læreplanene, valg av begrunnelse for læringsarbeid, gjennomføring og vurdering av læringsarbeidet (Haaland \& Nilsen, 2013, s. 43).

I følge John Dewey er demokrati et viktig element i utdanning og i et danningsperspektiv. Han så ikke på demokrati bare i et politisk system, men anså det for å være en individuell livsholdning. "Et demokrati er mer enn en styreform - det er primært en form for liv i forening med andre og en felles kommunikasjonserfaring” (Dewey, 1966/1916, s. 104). Dewey mente skolen, som en av samfunnets viktigste institusjoner hadde ansvar for å gi elevene utviklingsmuligheter og rom for personlig vekst. Skolen skal ikke være et sted hvor eleven blir forberedt til en gitt rolle i samfunnet, men et sted hvor eleven er aktiv og nysgjerrig i sin identitetsutvikling, et sted hvor eleven ble involvert og fikk medbestemmelse. Det er i følge Dewey ikke lærerens rolle å påtvinge elevene kunnskap, bestemme metoder eller lage regler for adferd, men å sikre eleven vekst og utvikling (Dewey, 1938, s. 8). Deweys tanker omkring elevens personlige utvikling kan knyttes til Kember, Ho og Hong`s teori om viktige virkemidler for å motivere studentene, som de mente var å etablere relevans. Deres forskning 
viste at etablering av relevans var den mest framtredende og ofte siterte studentresponsen hvor det ble hevdet at dersom læringen skulle gi mening måtte det etableres en koherens mellom personlig og den reelle verden som i denne sammenheng kan knyttes til elevens personlige erfaringer og levd liv. En nøkkelfaktor som fremkom i deres studie var å gi elevene en læringskontekst der elevene konstruerer sin egen relevans og forståelse av innholdet (Kember, Ho, \& Hong, 2008). I yrkesfaglig utdanning kan dette knyttes til den enkelte elevs yrkesvalg og/eller interesse, som læringsarbeidet kan rettes mot. I følge Kellers tanker omkring elevenes læringskontekts er det å fange elevenes oppmerksomhet helt nødvendig for motivasjonen og læringen hvor utfordringen er å stimulere og opprettholde elevenes oppmerksomhet over tid (Keller, 2010, s. 76).

\section{Forskningstilnærmingen i prosjektet}

For å svare på problemstillingen om hvordan utvikle en yrkesrelevant og meningsfull undervisning $i \mathrm{Vg} 1, B A$ og $\mathrm{DH}$ er datagrunnlaget basert på en kvalitativ studie gjennom fire fokusgruppeintervjuer med lærere i fem utdanningsprogram som i denne sammenheng inngår som en del av aksjonsforskningsforløpet. Det empiriske materialet som ligger til grunn er innhentet gjennom fokusgruppeintervjuene og tiltakene i form av oppgavetekster, undervisningsplaner, dokumentasjon av elevarbeider, samt spørreunders $\varnothing$ kelser. Tiltakene ble gjennomført i et aksjonsforskningsforløp. Aksjonsforskningsprosjektet er forankret i den nordiske tradisjonen og har elementer fra både den pedagogiske og den dialogpregede tilnærmingen. Reason og Bradbury (2001) omtaler denne type aksjonsforskning som demokratisk dialogtradisjon.

I følge Greenwood og Levin (2007) er aksjonsforskning et sett selvbevisste samarbeids- og demokratiskorienterte strategier for å genere kunnskap og designe handling $\mathrm{i}$ et samarbeid gjennom trenede aksjonsforskere og lokale interessenter. Aksjonsforskningens styrke er relevans, først og fremst til feltet (Amble, Møller \& Vagle, 2017) som i dette tilfelle handler om relevans for yrkesopplæringen. Dette aksjonsforskningsprosjektet består av fire fokusgruppeintervjuer og to tiltak for å videreutvikle relevant undervisning, for elever med ulike utdanningsmål, i to $\mathrm{Vg} 1$ klasser.

Aksjonsforskning betyr her at erfaringer fra en fase i prosessen trekkes inn og brukes som grunnlag for neste fase. Første fase i forløpet bestod av første fokusgruppeintervju med 
kartlegging av nåsituasjon, ønsket situasjon, planlegging av første tiltak og gjennomføring av tiltak 1. Andre fase var fokusgruppeintervju 2 hvor erfaringer fra første tiltak ble delt og lagt til grunn for evaluering og planlegging av neste tiltak 2 . Tredje fase var individuell veiledning på egne tiltak. Fjerde fase var gjennomføring og evaluering av tiltak to i klassene. Avslutningsvis i fase fire ble det gjennomført fokusgruppeintervju som omhandlet hele utviklingsprosessen, resultatene av tiltakene, lærers utvikling og endring, samt veien videre.

\section{Min rolle i prosjektet}

Jeg var involvert i planleggingen, gjennomføring og vurdering av alle tiltakene, i ulik grad.

Siden tiltakene ble utført på forskjellige tidspunkt ble min involvering både via tilstedeværelse i selve gjennomføringen av tiltakene, individuelle veiledninger, fokusgruppemøter, samt veiledning via mail og telefon. Evalueringen og eventuelle justeringer mellom tiltak en og tiltak to ble stort sett gjennomført i plenum på fokusgruppemøte og via spørreunderøkelsene etter tiltakene.

\section{Fokusgruppe}

For å få frem ulike perspektiver på utvikling av undervisning ble fokusgruppen sammensatt med lærere fra fem utdanningsprogram. Samarbeid på tvers av fag kan bidra til en interessant og viktig diskusjon med tanke på breddekunnskap innenfor problemstillingen. Dette var grunnen til jeg valgte fem utdanningsprogram i fokusgruppen - ikke bare de to som blir presentert i artikkelen.

Fokusgruppeintervjuene hadde en uformell stil hvor gruppemedlemmene diskuterte og drøftet ulike utfordringer knyttet til utviklingen av tiltakene, og tema som jeg på forhand ikke hadde forutsatt, men som var interessant å forfølge videre ble tatt opp. Begrunnelsen for valg av fokusgruppeintervjuer er, å lære av prosessen underveis og bruke fleksibiliteten til å justere kursen (Malterud, 2011, s. 135). Det ble gjennomført fire fokusgruppeintervjuer hvor jeg som forsker ønsket å få frem lærernes tanker omkring temaene som kom frem gjennom samtalene. Tema for gruppeintervjuene var i hovedsak; relevant og meningsfull yrkesopplaring - et demokratisk blikk på innhold og arbeidsmåter. Jeg hadde i liten grad rolle som intervjuer, men mer en ordstyrer og organisator som hadde ansvar for å drive samtalen fremover og holde fokus. Det første og siste intervjuet ble tatt opp på bånd, transkribert og skrevet ut på papir. De to andre fokusgruppemøtene ble ikke tatt opp på bånd da disse hadde fokus på de individuelle tiltakene hvor deltakerne presenterte sine planer og tiltak for hverandre og det ble gitt individuelle tilbakemeldinger både fra meg og resten av gruppen til hver enkel deltaker. 
Det som skiller fokusgruppeintervju fra individuelle intervjuer, er potensialet for samhandling imellom deltakerne, noe som var viktig i dette aksjonsforskningsprosjektet (Malterud, 2011, s. 133). Det var viktig for alle involverte at eksemplene som ble utviklet gjennom tiltakene, ble utviklet for den fremtidige undervisningen, ikke bare i prosjektperioden. Det var ikke noe hensikt å utvikle utopiske eller hypotetiske undervisningsformer som ikke lar seg gjennomføre i en reell skolesituasjon.

Det var et ønske fra lærerne at tiltakene ble gjennomført fra skoleoppstart på høsten, derfor ble det første fokusgruppemøtet gjennomført i mai 2016. Det første fokusgruppemøtet hadde hovedfokus på å utvikle skisse til eget utviklingsarbeid, samt planlegging av tiltakene. Prosjektperioden avsluttet i mars 2017.

\section{Spørreundersøkelse}

Spørreundersøkelsen ble gjennomført i klassene etter hver av de to tiltakene. Unders $\varnothing$ kelsene gav tilbakemelding til lærer på hva som fungerte bra og hva som kan videreutvikles i utviklingen av en relevant og meningsfull undervisning. Undersøkelsene fungerte som en metode for innhenting av empiri og er i denne sammenheng en del av tiltakene.

Spørreundersøkelsen ble planlagt og utarbeidet av lærerne og dannet grunnlag for endring og justering for neste tiltak. Undersøkelsene ble gjennomført etter begge tiltakene.

Undersøkelsene var halvstrukturerte spørreskjema, med både avkrysning og utdyping med egne ord, noe som gir resultatene fra elevene en kombinasjon av kvantitative og kvalitative data. Utdypingene gav kvalitative data for beskrivelse, analyse og tolkning av karaktertrekk og egenskaper, eller kvaliteter ved de fenomenene som ble studert (Malterud, 2017, s. 30). Materialet består av tekst som kan representere samtaler eller observasjoner, mens den kvantitative delen bygger på numeriske data i form av tall (Malterud, 2013). Den samlede empirien kan belyse ulike opplevelser av samme virkelighet og bidra til et nyansert og mangfoldig perspektiv på opplevelsen av relevans i undervisningen. Spørsmålene i spørreundersøkelsene ble drøftet med meg for å sikre at spørsmålene hadde fokus på relevans av undervisningens innhold i tråd med interesser og/eller yrkesplaner og at spørsmålene var formulert slik at de gav nyttig tilbakemelding i utviklingsfasen. Lærerne oppsummerte svarene selv, som grunnlag for evaluering av egen undervisning og læring, samt planlegging av videre utvikling. Svarene inngår også i det empiriske datagrunnlaget for 
aksjonsforskningen og analyseres, på samme måte som fokusgruppeintervjuene, som grunnlag for å belyse artikkelens problemstilling.

\section{Analysens fremdrift}

Studien bygger på en fenomenologisk og hermeneutisk tilnærming for å løfte frem lærerne og elevenes subjektive meninger. I analysearbeidet ble hermeneutisk fortolkning brukt for å sammenfatte innholdet i fokusgruppeintervjuene. Steinar Kvale hevder at det viktigste i denne fasen er å være tydelig på hvilket spørsmål en stiller datamaterialet (Kvale, 1996, s. 210). Det betyr at fortolkninger man gjør av meningsdannelse, avhenger av disse spørsmålene (Halkier, 2010, s. 91). Analysen av fokusgruppeintervjuene er en modifisert utgave av Amadeo Giorgi analysemodell. Georgios analysemodell er i hovedsak utarbeidet for dybdeintervju, men modellen fungerer også godt for fokusgruppeintervjuer.

Gjennom transkribering og grundig gjennomgang av intervjuene ble jeg 'kjent' med innholdet i datamaterialet og dannet meg et bilde av hovedmomentene i samtalen hvor meningsinnholdet ble analysert ved hjelp av meningsfortetting. Den første fasen i analysen hadde fokus på å utforske og beskrive lærernes erfaringer med, og forståelse av undervisning i egen klasse (Creswell, 2009, s. 57; Garmanslund \& Witsø, 2017; Johannessen, Tufte \& Kristoffersen, 2004, s. 76;). I denne fasen dannes et helhetsinntrykk over dataene som grunnlag for en fortetting av meningsinnholdet (Garmanslund \& Witsø, 2017; Johannessen et al., 2016, s. 173).

I andre fase av analysen ble helhetsinntrykket knyttet til hovedtemaene som utspant seg gjennom samtalene. Kategoriene elevinvolvering, elevmedvirkning, innhold og organisering, yrkesretting, nasjonale føringer, samt begrepet demokrati i skolehverdagen utkrystalliserte seg i denne fasen. I den tredje fasen ble kategorier som innholdsmessig kunne omfavne samme betydning slått sammen til kategoriene; elevfokus, elevmedvirkning, yrkesretting og demokratisk medbestemmelse. Noe som bidrog til at jeg i denne fasen abstraherte meningsinnholdet i kodene som utspant seg gjennom gruppemøtene. Hovedmålet med de ulike analysetemaene er i følge Giorgi (1985) at teksten skal danne et helhetsbilde som gir grunnlag for neste steg. Helhetsinntrykket knyttes til problemstillingen, abstrahere og løfte blikket på det en har gjort slik at dataene tilslutt ble re- kontekstualisert. 
Oversikten jeg fikk gjennom samtaler, notater, lydopptak og selve transkripsjonen gav meg et helhetsinntrykk over innhold, samt interaksjonen i gruppen. Underveis i analyseprosessen har jeg gått tilbake både til lydopptak og transkripsjon, jeg har notert nye oppdagelser og nye refleksjoner som igjen har bidratt til ytterlige forståelse og helhetsinntrykk. Malterud presiserer viktigheten av å motstå all trang til å systematisere innholdet på et tidlig stadium og før alle data er grundig gjennomgått (Malterud, 2013, s. 99). I den sammenheng har jeg vært spesielt oppmerksom på egen forforståelse for ikke å trekke slutninger før jeg hadde satt meg grundig inn i alle svarene og arbeidet systematisk gjennom alle fasene $\mathrm{i}$ analysen.

\section{Utvalg av informanter}

Det ble gjennomført fire fokusgruppeintervju med til sammen seks lærere representert fra utdanningsprogrammene Design og håndverk (DH), Helse og oppvekst (HO), Elektro (EL), Bygg og anleggsteknikk (BA), Teknikk og industriell produksjon (TIP). Unders $\varnothing$ kelsene ble gjennomført i til sammen seks klasser. Eksemplene som belyses i artikkelen er fra utdanningsprogrammene DH og BA. Antall elever som har deltatt er tretti.

\section{Validitet og forskningsetikk}

To av fokusgruppeintervjuet ble som tidligere nevnt tatt opp på bånd, transkribert systematisk gjennom hele prosessen og tilslutt skrevet ut på papir (Halkier, 2010, s. 81). For å bevare intersubjektiviteten i gruppeintervjuet gjennomførte jeg dialogisk validering som betyr å forsikre en felles forståelse og unngå misforståelser som kan føre til mistolking av rådata (Malterud, 2013, s. 182).

Utvalget i fokusgruppen representerer seks lærere fra fem av ni yrkesfaglige utdanningsprogram. Alle lærerne gjennomførte tiltak i egne klasser, men det vil bli for omfattende i forhold til artikkelens volum å utdype og diskutere alle tiltakene like grundig, noe som i tilfelle ville vært naturlig. Tiltakene fra BA og DH som presenteres er tilfeldig valgt. Erfaringen fra alle utdanningsprogrammene som var representert ble brukt $\mathrm{i}$ fokusgruppens diskusjoner og drøftinger, og bidro dermed til et bredere perspektiv på utvikling av en yrkesrelevant og meningsfull undervisning for elever med ulike utdanningsplaner i Vg1? Lærerne som gjennomførte tiltakene som presenteres i artikkelen har lest og gitt tilbakemelding på min forståelse av oppgavetekster og utviklingsskisser er i henhold til deres utsagn (Silvermann, 2004, s. 153). 
En svakhet med studien kan være at spørreundersøkelsene lærerne utførte, gjennom tiltakene i egne klasser, ble planlagt og gjennomført og evaluert av lærerne individuelt for så å bruke resultatene unders $\varnothing$ kelsen som grunnlag for nytt tiltak. Dette foregikk uten et samarbeid med meg. Jeg analyserte spørreunders $\varnothing$ kelsene i etterkant og bruker disse dataene inn i artikkelen. Manglende kjennskap til informantene og hvordan unders $\varnothing$ kelsene ble gjennomført, samt lærerens rolle, skaper distanse mellom forsker og feltet og kan dermed ha betydning for resultatet av analysen. Det kunne derfor vært interessant å gjennomføre dybdeintervjuer med noen elever for å undersøke forståelsen av utviklingen i klassene og hvordan resultatene fra spørreundersøkelsen samsvarer med resultatene fra fokusgruppeintervjuene.

Prosjektet er registret og vurdert av Norsk senter for Forskningsdata (NSD) Prosjekt. nr 42876. Innhenting og avklaring av data ble foretatt i henhold til nasjonale etiske retningslinjer og anbefalinger gitt av NSD.

\section{Resultater - Utvikling for yrkesrelevant og meningsfull undervisning}

Her presenteres tiltakene som ble gjennomført i Vg1 DH og Vg1 BA, resultatene av tiltakene, elevenes evaluering og endringene lærernes gjorde i prosjektperioden. Tiltakene tar utgangspunkt i lærernes individuelle utviklingsskisser som er utviklet med bakgrunn i SØT modellen. Modellen har fokus på nå situasjonen, ønsket situasjon og tiltak. Gapet mellom nå og ønsket situasjon er brukt til å reflektere og synliggjøre muligheter som finnes for å komme videre (Hartviksen \& Kversøy, 2008, s. 31).

\section{Eksempel 1. Design og Håndverk}

I sin utviklingsskisse har lærer hovedsakelig tre mål hun ønsker å ha fokus på og beskriver de slik; selvstendige og delaktige elever, bli en laerer/veileder $i$ stadig utvikling og endring som peker mot nye mål. Lærer har et ønske om å involvere elevene mer i planlegging og vurdering av undervisning og oppgaver slik at de tilpasses mer til den enkeltes yrkesplan og interesser. Normalt planlegger og vurderer hun alle oppgaver på egenhånd og beskriver ofte oppgavene detaljert. Dette mener hun kan 'låse' elevene fra å knytte oppgavene til egen yrkesplan og interesser og vil gjennom tiltak lage åpnere oppgavetekster som utfordrer elevene til å ta egne valg på bakgrunn av yrkesplaner og/eller interesser. Tiltak 1 er et eksempel på lærers beskrivelse av nå-situasjonen og er en oppgave innen tekstil og blir heretter kalt tekstiloppgave. Lærer sendte meg oppgaveteksten for veiledning hvor jeg utfordret henne spesielt på innhold og omfang sett opp mot egen utviklingsskisse. Oppgaven bar preg av mye 
tekst med informasjon, samt forslag og råd om hvordan oppgaven kunne løses. Lærer justerte teksten noe etter veiledning, men oppgaveteksten bar fortsatt preg av mye informasjon og begrenset mulighet for at elevene kunne velge selv for å gjøre undervisningen relevant $\mathrm{i}$ forhold til sine yrkesinteresser. En tekstiloppgave, hvor alle elevene uavhengig av hva de ville utdanne seg til skulle lage et tekstilprodukt. Oppgaven blir i denne klassen gjennomført hver høst.

Tiltak 2 er en yrkesrettet oppgave hvor elevene velger et produkt de skal lage basert på egne yrkesinteresser, heretter kalt yrkesrettet oppgave. Oppgaven ble planlagt og gjennomført i samarbeid med meg. Oppgaven var kort og konsis med lite tekst, samt utfordret elevene til egne valg. Oppgaveteksten var åpen for å yrkesrette i henhold til egen yrkesplan eller yrkesinteresser.

\section{Eksempel 2. Bygg og Anlegg}

Lærer i BA har et tydelig mål om ønsket situasjon som han beskriver slik; tett samarbeid mellom bedrift, programfag og fellesfag. Elevmedvirkning hvor elevene bidrar i planlegging, gjennomføring og evaluering. Han mener et samarbeid mellom fellesfag og programfag kan bidra til en helhetlig, relevant og fremtidsrettet undervisning. Det er dette som er hovedfokuset i eksemplene som presenteres.

Tiltak 1 representerer i stor grad det læreren beskriver som nå-situasjonen i egen undervisning. Oppgaven handler om montering av boder til et julemarked, heretter kalt juleprosjekt. Juleprosjektet er et prosjekt Bygg og anlegg gjennomfører hver høst med fokus på programfaget.

Tiltak 2 representerer i større grad prosessen mot $\phi$ nsket- situasjon og er en norsk oppgave med hovedfokus på programfaget, heretter kalt norskoppgave. Denne gangen har programfaglærer inngått et samarbeid med norskfaglærer som skal vurdere den skriftlige dokumentasjonen. I norskoppgaven er oppgaveteksten utarbeidet i fellesskap mellom norsklærer og programfaglærer og handler om hvilke yrke eleven har valgt i programfaget yrkesfaglig fordypning (YFF). Elevene skal beskrive yrket, hvilken utdannings som kreves, jobbmuligheter, yrkets særpreg etc. Oppgaveteksten er kort og konsis og inneholder planlegging, gjennomføring og vurdering.

\section{Resultat av tiltakene på Design og Håndverk}

Tekstiloppgaven gjennomføres som nevnt hver høst og representerer lærers nå-situasjon. Lærer har på bakgrunn av veiledning gjort noen endringer som for eksempel; forenklet 
oppgaveteksten for å gjøre oppgaven mer åpen for individuelle valg. Den yrkesrettede oppgaven ble gjennomført i etterkant av lærers og elevenes evaluering av tekstiloppgaven. Endringene og resultat er basert på elevenes tilbakemeldinger og lærers evaluering og viser utviklingen av lærers nå-situasjon og prosessene mot фnsket situasjon.

Tekstiloppgaven har en lang oppgavetekst med mange opplysninger og mye informasjon som for eksempel; mål, hensikt, vurderingskriterier, videre er det en rekke forslag til inspirasjon som viser vei til ferdig produkt. Å involvere elevene til elevmedvirkning og ta ansvar for egen læring og progresjon innebærer at elevene har mulighet å påvirke slik at oppgaven ivaretar elevens interesser og yrkesplaner. Sett opp mot lærers utviklingsskisse hvor selvstendige og delaktige elever var et av målene, gir ikke tekstiloppgaven rom for elevmedvirkning.

I den yrkesrettede oppgaven har lærer gjort endringer både med tanke på utarbeidelse av oppgavetekst og muligheter for elevmedvirkning gjennom planlegging, gjennomføring og evaluering. Oppgaven hadde en tydelig oppgavetekst som var åpen for individuelle valg av produkt/tjeneste i tråd med egne yrkesinteresser og oppfordret, samt utfordret elevene, til å bli kjent med det yrket elevene ønsket å utdanne seg til. For elever som ikke hadde bestemt seg for hvilke yrker de ønsket å utdanne seg til, utfordrer teksten dem til å ta noen valg som fører til at elevene blir bedre kjent med forskjellige yrker. Dette kan bidra til at elevene finner noen yrker interessante som de ønsker å bli mer kjent med, eller noen yrker som de ikke ønsker å arbeide med. Begge oppdagelsene er viktige og i tråd med Meld. St. 28 som sier at elevene har medansvar for, og rett til medvirkning i egen læring og påvirkning av egen skolehverdag (Meld. St. 28, 2015-2016, s. 22).

\section{Design og håndverk elevenes evaluering av tiltakene}

På spørsmålet om oppgavene var relevant for videre valg av yrke svarte over halvparten $(62 \%)$ at den yrkesrettede oppgaven var relevant, mens $8 \%$ mente at tekstiloppgaven var relevant for videre yrkesvalg. Den store forskjellen på svarene kan vise betydningen av at den yrkesrettede oppgaven har gitt elevene større frihet til å velge utfra egen interesse eller yrkesplan, at oppgaven bevisstgjorde hensikten med læringsoppgaven og at det var få eller ingen av elever som planla utdanning innen tekstilfaget. Et flertall av elevene mente at den yrkesrettede oppgaven bidro til å se sammenhenger mellom det de lærte gjennom oppgaven og det de skulle lære i læretiden. Et stort flertall (84\%) av elevene svarte at de ønsker mer av yrkesrettede oppgaver hvor de kunne påvirke innholdet slik at det var sammenheng med det de lærte på skolen og det de skulle utdanne seg til. Det kom tydelig frem at elevene (85\%) 
opplevde det motiverende å bestemme yrke selv. På tross av at tekstiloppgaven viser lite relevans i forhold til interesser og yrkesplaner mente noen (38\%) at tekstiloppgaven var motiverende. Det kom frem at å lære noe annet enn det de skulle utdanne seg til kunne motivere. Utsagn som; jeg vet jo at jeg kommer til å jobbe med fris $\phi r$, så hvorfor ikke lare å sy og strikke nå når jeg har muligheten. Dette er ikke i tråd med føringene for yrkesopplæringen slik jeg ser det, hvor dybdekompetanse blir sett på som et viktig ledd i utdanningen. I følge St.meld. 28 kjennetegnes dybdekompetanse ved at elevene får jobbe med lærestoffet over tid, og at de får tilbakemeldinger og utfordringer som er i takt med deres faglige utvikling (Meld. St. 28, 2015-2016). På spørsmål om hva som var spesielt bra med tekstiloppgaven, svarte elevene blant annet; at jeg fikk velge hva vi ville strikke, at det ikke var så mye teori, jeg hadde mer frihet til å gjøre oppgaven slik jeg vil. På den yrkesrettede oppgaven utpekte punkter som; at jeg kunne velge yrke, at vi fikk фve oss på det vi har lyst til. På spørsmålet om hva som kunne vært gjort oppgaven mer relevant svarte elevene i henhold til tekstiloppgaven; den var ikke relevant siden jeg har lyst til å bli frisør ...vi kunne gjort flere ting av det vi vil bli ... strikking og frisфr har ikke mye tilfelles. I henhold til den yrkesrettede oppgaven svarte elevene; mer materiale tilpasset ulike yrkesvalg og lignende.

Disse utsagnene er i tråd med føringene som hevder at skal opplæringen fremme læring må elevene engasjeres og være aktiv og de må få utfordringer som gjør at de strekker seg, samt utvikle dybdekompetanse for å forstå, og se sammenhenger (NOU, 2015, s. 74). Elevsvarene viser tydelig at det å kunne velge yrker i forhold til egne interesser eller yrkesplan er svært viktig for å oppleve at det de lærer på Vg1 er relevant og gir mening til elevenes utdanning og/eller yrkesvei. Dette er i tråd med Meld. St. 22 (2010-2011) som sier at skal elevene forstå hvorfor de skal bruke tiden på skolearbeid, må de oppleve undervisningen som relevant og meningsfull. Meldingen omhandler ungdomstrinnet, men det er ingen grunn til å tro at det er forskjell på elever på ungdomstrinnet og første året i videregående skole.

Meldinger poengterer også viktigheten av relevansen mellom det en lærer på skolen og det den kan brukes til i framtidig utdanning og yrke (Meld. St. 22, 2010-2011, s. 15).

\section{Endring av undervisningen på Design og håndverk}

Tiltakene viser svært ulike måter å tenke elevmedvirkning og yrkesretting på. I samtale med lærer mellom tiltak 1 og 2 gir lærer uttrykk for at hun tror elevene er for usikre og unge til å ta ansvar for egen læringshverdag. Videre sier hun at når oppgavene er detaljerte, slik som tekstiloppgaven var, mener hun det er enklere for eleven å forstå, samt gjennomføre 
oppgavene. Elevsvarene viser det motsatte, at elevene blir motivert av å bli utfordret, få ansvar og være involvert $\mathrm{i}$ undervisningen.

Etter tiltakene var gjennomført og evaluert mente lærer i Design og håndverk at hun gjennom oppgaveteksten på tekstiloppgaven hadde styrt elevenes valg og fratatt dem muligheten til å medvirke. Noe av det lærer uttrykte forundring over var hvor mange ulike yrker som ble representert gjennom den yrkesrettede oppgaven, at elevene kom rask i gang med oppgaven, elevenes motivasjon, få spørsmål, effektivitet i både plan, gjennomføring og vurdering, samt effektive og varierte dokumentasjoner. På fokusgruppeintervjuet i etterkant sa læreren; jeg har fått en aha opplevelse av hvor enkel en oppgave kan vare.

\section{Resultat av tiltak på Bygg og Anlegg}

Endringene og resultatet basert på elevenes tilbakemeldinger og lærers evaluering, viser en utvikling av lærers nå-situasjon og prosessene mot фnsket situasjon fra Juleprosjektet til Norskoppgaven.

Juleprosjektet viser som tidligere nevnt lærers nå-situasjon, men med noen endringer i form av valgmuligheter for elevene. Endringene fra tidligere år i juleprosjektet er lærers samarbeid med norsklærer hvor norsklærer skal vurdere dokumentasjonen i lys av kompetansemålene i norskfaget. Oppgaveteksten i juleprosjektet handler om programfaget og beskriver detaljert hva oppgaven skal inneholde, samt eksempler på hvordan den kan gjennomføres.

Oppgaveteksten er utarbeidet av programfaglærer, den gir lite rom for elevmedvirkning og kan forstås som en instruks til hvordan oppgaven skal gjennomføres.

Norskoppgavens innhold omhandler programfaget og dokumentasjonen blir vurdert i henhold til fellesfagets kompetansemål. Her skal elevene velge et yrke i henhold til egen yrkesplan i programfaget YFF hvor de skal innhente opplysninger om yrket. Hensikten med oppgaven er at de skal bli kjent med et yrke de ønsker å utdanne seg til, for å kunne gjøre et sikrere valg når den tid kommer. Oppgaveteksten er åpen og utfordrer elevene til å kontakte bedrifter for å innhente opplysninger om yrket. Sett opp mot lærers utviklingsskisse er målene godt ivaretatt. Oppgaven krever elevmedvirkning hvor eleven blir utfordret til å kontakte bedrifter for å innhente kunnskaper om både bedriften og bransjen generelt. Oppgaven gir rom for utvikling av dybdekunnskap og kanskje også ferdigheter for elever som har bestemt seg for framtidig yrke. Den gir samtidig muligheter for elever som er usikre på hva de ønsker å utdanne seg til, til å bli bedre kjent med yrkene i utdanningsprogrammet. Oppgaven er planlagt i samarbeid med norskfaglærer som skal vurdere den skriftlige og visuelle 
dokumentasjonen, mens yrkesfaglæreren vurderer det yrkesfaglige innholdet i elevenes dokumentasjon, relatert til programfagene. Læringsmål og vurderingskriterier er tydelige i forhold til hva som skal vektlegges i både programfag og norskfaget.

\section{Bygg og anlegg elevenes evaluering av tiltakene}

Nå-situasjonen for lærer ved BA var blant annet lite samarbeid med fellesfaglaererne, noe han $\emptyset$ nsket å endre på. Han kontaktet norsklærer før tiltakene og har derfor gjennomført begge oppgavene med fokus på egen skisse til utviklingsarbeidet $i$ klassen. Undersøkelsen etter juleprosjektet viser at elevene er svært positive til at antall skriftlige innleveringer blir redusert fra to til en, ved at norsk blir integrert i programfaget, noe utsagn fra elev bekrefter; vi slår 2 fluer $i$ en smekk ved å ha innlevering i yrkesretning og norsk samtidig. Samme elev mente også at det krevde mer innsats ved at det var to innleveringer og mente at; det var litt stress og måtte tenke på at jeg måtte skrive riktig norsk grammatikk mens jeg skrev monteringsanvisningen, men det er veldig mye mindre stress når vi slipper å ha 2 innlevering. Elevene mente også at det var enklere å dokumentere praktisk arbeid enn det å beskrive noe de ikke hadde praktisk erfaring med. Utsagn som; Det var ikke vanskelig å beskrive fordi vi hadde jobbet med det ... det var gфy å skrive noe som jeg hadde gjort sjøl ... det gikk bra fordi jeg kunne stoffet jeg skrev om. Disse utsagnene viser at elevene opplever skriveprosessen som enklere da de har jobbet med det de skriver om. Utsagnene viser også at når vurderingskriteriene for norskfaget er knyttet opp mot programfaget gir det mening og oppleves som mer relevant enn når det ikke har sammenheng med programfaget. Dette støttes av nyere forskning som viser til at skal teoriundervisning oppleves relevant må det knyttes til praksis (Sylte \& Jahanlu, 2017). En elev sier det slik; når vi har innleveringer om noe vi har gjort $i$ praksis synes jeg det er enklere å forklare og skrive om det. Et stort flertall av elevene (94\%) mente at norskfaget ble mer interessant når det ble knyttet til programfaget og at sammenhengen mellom fagene ble tydeligere, noe som bidro til $\varnothing \mathrm{kt}$ motivasjon for norskfaget og en opplevelse av at norskfaget ble interessant, relevant og nyttig. Dette bekrefter utsagn som; selve norsken er ikke motiverende, men når vi kan laere ting vi har gjort i praksis så er det egentlig ganske greit. Samtlige elever mente norskfaget var relevant når de skulle utarbeide formelle tekster som jobbsøknad og CV og at det var i den sammenheng de ville få mest bruk for det. De fleste elevene (94\%) mente at yrkesrettet undervisning var å foretrekke fremfor tradisjonell norskundervisning og utsagn som; på Vgl har på en måte fagene snakket sammen og her laerer vi ting vi trenger å kunne i fremtiden. Dette tyder på at arbeidslivet og 
fremtiden er viktig for elevenes opplevelse av relevans, mellom det som læres på skolen, og det den enkelte eleven er interessert i eller skal utdanne seg til. I følge Dewey kan medbestemmelse slik eleven viser i sine utsagn, ses sammen med betydningen av demokratisk medvirkning. Han hevder at demokrati nettopp er at den enkelte skal kunne bestemme vilkårene og målene for sitt eget arbeid (Vaage, 2000, s. 89).

\section{Endring av undervisningen i Bygg og anlegg}

Lærer gjennomførte endringer allerede ved første tiltak, som var juleprosjektet. Her etablerte han et samarbeid med norsklærer hvor dokumentasjonen av juleprosjektet skulle vurderes $\mathrm{i}$ henhold til kompetansemål i norskfaget. Det er likevel en tydelig forskjell på juleprosjektet og norskoppgaven. Gjennomføringen av juleprosjektet ble utført på samme måte som tidligere, men dokumentasjonen skulle nå vurderes av norsklærer. Elevenes tilbakemeldinger på at juleprosjektet skulle omhandle både fellesfag og programfag var blant annet; bra at vi kunne ha denne innleveringen som både gikk på Yrkesretting og norsk slik at vi slapp å ha to store innleveringer og det var gфyere siden det er praksis og ikke bare teoretisk. Med noen små endringer kan juleprosjektet enkelt tilpasses utdanningsplaner og interesser slik at elevene opplever både programfaget og norskfaget relevant.

Norskoppgaven som ikke hadde hatt noen sammenheng med programfaget tidligere, omhandlet nå programfaget rettet mot det yrket eleven ønsket å fordype seg i. Elevene hadde stor valgfrihet og måtte selv ta ansvar for oppgavens relevans gjennom valg av yrke og arbeidsmåter. Oppgaven utfordret elevene til å kontakte bedrifter for å bli bedre kjent med og kanskje få prøve seg litt på faglig arbeid i yrket. Både fellesfaglærer og programfaglærer var involvert i norskoppgaven i henhold til planlegging, gjennomføring og vurdering. Gjennom fokusgruppemøtene kom det frem at norskfag - og programfaglæreren opplevde samarbeidet som svært positivt.

\section{Diskusjon}

I dette kapittelet diskuteres lærernes utvikling opp i mot teorigrunnlaget, nasjonale føringer og tidligere forskning, samt problemstillingen: Hvordan utvikle en yrkesrelevant og meningsfull undervisning for elever med ulike utdanningsplaner $i \mathrm{Vg} 1$ ?

Gjennom fokusgruppeintervju kommer det frem at lærerne føler seg bundet til læreplanene, selv om, i følge dem selv, ønsker å gi elevene større frihet. De opplever det vanskelig å tolke 
kompetansemålene direkte mot elevens interesser og/eller yrkesplaner. En av lærerne sa det slik; det er enklere å følge planen slik den fremstår for å sikre at jeg har gjennomført jobben som er forventet. Lærerne var også opptatt av å tilpasse undervisningen gjennom differensiering i henhold til nivå og tidsbruk, men mindre til innholdet, til tross for uttalelser som drømmen må vare å gi elevene frihet til å arbeide med egne interesser/yrkesplaner så tidlig som mulig i skoleåret, for å opprettholde motivasjonen.

En slik innstilling støttes av Kellers (2010) som hevder det er avgjørende for utvikling og opprettholdelse av motivasjon, at mål og nytteverdien av kunnskapen knyttes til fremtidig yrke eller videre skolering. Videre hevder Keller at selv om det oppstår nysgjerrighet vil en miste motivasjonen dersom innholdet $\mathrm{i}$ undervisningen ikke har noen relevans med elevens mål og læringsbehov, og at nysgjerrigheten må opprettholdes for at motivasjonen skal vedvare (Keller, 2000). Dette kan knyttes til elevens individuelle læringsprosess hvor interesser og motivasjon er drivkraften. Det gjør den enkeltes handlingsrom, plass og funksjon i demokratiske arbeids- og læringsarenaer til nødvendige forutsetninger i læring og personlig utvikling (Haaland \& Nilsen, 2013, s. 40). Det innebærer å utvikle en undervisning som oppleves relevant for alle basert på egne forutsetninger, behov og interesser.

Å involvere elevene i å gi tilbakemeldinger på undervisningen var noe lærerne opplevde som 'skummelt', noe som i følge Hiim (2007, s. 54) er nødvendig i en utviklingsprosess. Videre påpeker hun at demokratisk læringsarbeid forutsetter muligheter for kritikk og endring av eksisterende opplæringstradisjoner. Elevenes evaluering gjennom spørreunders $ø$ kelsene hadde fokus på innhold og metoder. Elevene gav respons på hvordan de opplevde nytteverdien av det de lærte på skolen i forhold til egne interesser eller yrkesplaner. Etter hvert ble involvering av elevene i evalueringsarbeidet ikke bare viktig, men naturlig for lærerne. Tidligere planla, gjennomførte og evaluerte lærerne oppgaver og prosjekter uten å involvere elevene. Oppgavene bar preg av å være lik for alle, uavhengig av interesser og yrkesplaner. Dette gjaldt også individuelle mål og vurderingskriterier. Dette kom frem gjennom det første fokusgruppeintervjuet hvor en av lærerne sa; noen elever evner ikke til å ta del $i$ undervisningen, de er forn $\phi y d$ med å bli fortalt hvordan ting skal gjøres. Andre lærere mente elevene opplevde det som stress å medvirke og at det bare var de mest aktive og motiverte elevene som ville være med å bestemme. De mente at elever som 'strevde' hverken klarte eller ønsket å medvirke. 
Å skape helhet og sammenheng er et nasjonalt mål (St.meld. nr. 30, 2003-2004). For fag - og yrkesopplæringen betyr det i følge Haaland og Nilsen (2013, s. 46) at opplæringen skal henge godt sammen, både når det gjelder innhold og arbeidsmåter. Undervisningen skal være forankret i yrket elevene utdanner seg til og Vg1 skal være et solid grunnlag for alle elever og deres yrkesvalg i det aktuelle utdanningsprogrammet. I ettertid av tiltakene endret lærerne i denne studien mening, og hevder at involvering og medvirkning i egen skolehverdag påvirket motivasjonen, samt bidrog til at elevene fikk mer eierskap til egen læring og utvikling. Eierskapet gjelder for eksempel hvilke kunnskaper og kompetanse som kreves i de ulike yrkene etter gjennomført Vg1 og Vg2. Evalueringene viser at det er avgjørende for elevenes arbeids- og lærelyst at arbeidsoppgavene har utgangspunkt i elevens interesser. I og med at elevene i Vg1 har ulike interesser og yrkesplaner kreves det at undervisningen interessedifferensieres for å motivere for læring (Haaland \& Nilsen, 2013, s. 40). Demokrati som skal være bærebjelken i Norsk utdanning, betyr i følge Nasjonale føringer at elever og læringer skal utvikle kompetanse til å delta i demokratiske fellesskaper. Elevene skal bli sett, hørt og tatt på alvor, samt lære å ivareta markedets behov for produkter og tjenester på en samfunnstjenlig måte (Hansen \& Haaland, 2015, s. 26). Å se sammenheng med det som læres på skolen og det som er elevens yrkesplan eller yrkesinteresse er avgjørende for motivasjonen, noe tiltaket gjennomført med norsklærer i BA viser. Norskoppgaven var åpen for individuelle valg i tråd med egne yrkesinteresser, den oppfordret og utfordret elevene til å bli kjent med det yrket de ønsket å utdanne seg til. I følge Keller må elevene oppleve at undervisningen relateres til viktige personlige mål for å bli motivert for læring, som i yrkesopplæringen i stor grad handler om elevenes yrkesinteresser (Keller, 2010, s. 45). Hiim argumenterer for at yrkesrelevant og realistisk arbeidslivspraksis er grunnleggende nødvendig for at elevene skal kunne gjøre sikre valg av yrke og for å utvikle et erfaringsbasert faglig grunnlag i yrker de er interessert i og ønsker å utdanne seg til (Hiim, 2013).

Gjennom fokusgruppeintervjuene kommer det tydelig frem at fokusgruppemøtene har vært viktig i utviklingsprosessen. Samlingene og forventningene til hverandre har medvirket til fremdrift for hver enkelt lærers utviklingsprosess. Utsagn som; jeg har prøvd noe som sannsynligvis ikke jeg hadde prøvd uten denne gruppen for selv om vi ikke underviser $i$ samme fag, får vi ideer og tips til egen undervisning. Utsagnene kan tyde på opplevelse av utvikling i et samarbeid med lærere på tvers av utdanningsprogram og fag. Justeringene lærerne gjennomførte i forbindelse med tiltakene viser at å involvere elevene i 
utviklingsprosessen, har vært avgjørende i endrings- og utviklingsprosessen. Elevenes tilbakemelding til lærerne på om innholdet i undervisningen opplevdes relevant, har gitt lærerne en viktig pekepinn på hvor de er i henhold til utvikling i prosessen mot $\phi n s k e t$ situasjon. Disse tilbakemeldingene må lærerne integrere og tilpasse til læreplanene slik at innholdet er til nytte for den enkelte elevs fremtidsplaner og at eleven tilegner seg kunnskaper som er forventet etter gjennomført Vg1.

Forskning og evaluering av (KL06) viser at mange skoleeiere, skoleledere og lærere tolker læreplanene i de brede utdanningsprogrammene til at elevene skal ha introduksjon i flere yrker, spesielt i Vg1. Elevene blir pålagt en generell undervisning, som ikke er relatert til yrker de utdanner seg til, eller en 'smakebitspedagogikk' med introduksjon til mange yrker gjennom modulbasert undervisning (Dahlback et al., 2011; Bødtker-Lund et al., 2017; Sylte, 2015). Dette til tross for at flertallet av elevene har klare yrkesplaner (Dahlbach, et.al, 2011; Hiim, 2013). I følge NOU 2015:8 blir fagspesifikk kompetanse eller dybdelaering, samt det $\stackrel{a}{~}$ kunne lare, fremhevet som to av fire kompetanseområder som skal vektlegges i fremtidens skole. Dette fordrer at elevene får tid og rom til å fordype seg i ett spesifikt yrke dersom de $\emptyset$ nsker det. Dette støttes av Dewey som mente det er viktig at elevene blir tildelt og tar en aktiv rolle i skolen der medbestemmelse står sentralt (Madsen \& Munch, 2008, s. 55). Læringsmiljøet skal være demokratisk ved at elevene utvikler kompetanse til å bli kritiske individer som kan ta egne standpunkt. Da må de også bli sett på og akseptert som ansvarsfulle individer med personlige meninger, erfaringer og læringsbehov (Møller \& Sundli, 2007, s. 115-6). Elevmedvirkning bygger således mye på Deweys filosofi hvor hans tanker om demokrati, utdanning til lederskap og ansvar for egne handlinger, medfører at elevene må gis handlingsrom, medansvar og innflytelse i sin egen utdanning. Skolen må anerkjenne elevenes kunnskap og hva de som subjekter har å bidra med i utforming av egen utdanning for å sikre at elevenes behov blir ivaretatt og utvikling av indre motivasjon er mulig (Madsen \& Munch, 2008, s. 59). I denne sammenheng kan det bety involvering, medbestemmelse, samt individuelle valg som bidrar til at læring og utvikling gjennom $\mathrm{Vg} 1$, oppleves relevant og meningsfylt.

\section{Oppsummering}

Gjennom utvikling av eksempler på relevant og meningsfull undervisning har deltakerne i fokusgruppen diskutert, drøftet og utfordret hverandre på felles og individuelle fokusområder. Lærerne har i samarbeid med elevene utviklet eksempler, gjennom tiltak som består av 
planlegging, gjennomføring og evaluering. De har endret og tilpasset innholdet for å sikre at eleven opplever undervisningen relevant i forhold til egne interesser/yrkesplaner. Oppgaver som tidligere var lærerstyrte og lite tilpasset den enkelte, har de endret til åpne oppgaver som krever elevmedvirkning. Lærerne utfordrer elevene i henhold til gjennomføring og evaluering tilpasset egne interesser/yrkesplaner. Lærerne har gjennom spørreunders økelser og samtaler med elevene gjennomført aksjonsforskning hvor elevene har bidratt i evalueringen av tiltakene som igjen har vært grunnlag for endring og utvikling av neste til tiltak (Greenwood \& Levin, 2007).

Jevnt over opplever lærerne en utvikling fra nå- til фnsket situasjon, men med ulike forutsetninger og progresjon. Fra oppstart og til prosjektet avsluttet kommer det frem at lærerne har endret fokus når de planlegger undervisning. Fra å tenke generell yrkesretting, hvor undervisningen omhandlet et hvilket som helst yrke, har de endret det til å planlegge i henhold til den enkeltes elevs interesser og/eller yrkesplaner. Lærerne har erfart hvordan elevmedvirkning og elevdemokrati kan styrke yrkesretting når eleven blir sett og hørt samt får frihet til å delta aktivt $\mathrm{i}$ egen utdanning og yrkesplan. Gjennom tiltakene har lærerne involvert elevene i planlegging, gjennomføring og evaluering av oppgaver, samt utfordret de på å ta valg relatert til egne interesser eller yrkesinteresser. For elever som er usikker på eget yrkesvalg har de gjennom oppgavene måtte velge et yrke de ønsket å bli bedre kjent med. Lærerne har også utfordret elevene på å gi tilbakemelding til lærerne på hvordan han/hun opplever undervisningen. I følge lærerne var dette en ny måte å tenke elevmedvirkning på. Lærerne opplevde dette som litt 'skummelt' i starten, men det kommer tydelig frem gjennom tiltakene at elevresponsen var viktig i utviklingen av en yrkesrelevant og meningsfull undervisning tilpasset ulike utdanningsplaner. Uten elevenes involvering, mente lærerne at det hadde vært vanskelig å vite hvordan elevene opplevde undervisningen og hva som eventuelt burde endres eller justeres. Lærerne gav også uttrykk for at involveringen og samarbeidet gav positive relasjoner mellom lærer og elev og at elevene tok mer ansvar og viste mer engasjement og eierskap til innholdet $\mathrm{i}$ undervisningen.

Tiltakene som ble gjennomført har bidratt til lærerne har forsterket fokus på kvalitet i egen undervisning. Spørsmål som; er innholdet i undervisningen relevant, evt; for hvem? Hvordan gjøre den mer relevant? Hvordan involvere elevene, er spørsmål lærerne har stilt seg gjennom tiltakene. En av lærerne beskrev noe av det han hadde lært slik på siste fokusgruppemøte; det 
har vart spesielt å undersøke resultater av egen undervisning, for elevene opplever det ofte helt annerledes enn det eg selv tenker. Det har vart nyttig!

Lærerne har gjennom fokusgruppemøtene utfordret hverandre, noe som har bidratt til at lærerne har kjent på ansvaret for å drive tiltakene fremover. Spørsmålet er hvor mye fokusgruppemøtene har bidratt til nytenkning og endring. Hva nå når prosjektet er over og disse møtepunktene ikke eksisterer? I den sammenheng stiller jeg meg spørsmål hvor avgjørende fokusgruppesamlingene har spilt inn på fremdriften og resultatet i prosjektet og hvor viktig min involvering har vært i den sammenheng? Det kunne vært interessant å undersøke ved en senere anledning om lærerne har fortsatt å videreutvikle undervisning og læring i egne klasser, mot det de ved oppstart av prosjektet beskrev som фnsket situasjon, eller om de har beveget seg tilbake mot det de beskrev som nå situasjonen. Det ville gitt meg en pekepinn på hvilken påvirkning min rolle som forsker har hatt i prosjektet, noe som hadde vært viktig læring å ta med seg inn i fremtidige prosjekter.

Om strategien som er brukt i denne studien kan bidra til samme positive resultat for andre lærere er vanskelig å anslå, men relatert til relevant teori (Dewey,1938, 1966/1916) er det sannsynlig at resultatene har en viss overføringsverdi til andre utdanningsprogram og klasser. Videre ville det vært spennende å sett denne strategien inn i et perspektiv hvor helhetlig opplæring gjennom Vg1, Vg2 og Vg3 ble gjennomført i et samarbeidsprosjekt mellom lærere og elever. Et samarbeid som utfordret til involvering, medvirkning og demokratiske avgjørelser basert på elevenes behov, interesser og fremtidige yrkesplaner, og som gir lærerne rom til å tilpasse innholdet i undervisningen til det den enkelte elev trenger. Siden både elever og lærere opplevde større motivasjon, engasjement og eierforhold til undervisningen hadde det også vært spennende å undersøke hvordan undervisning med vektlegging på elevinnflytelse og medbestemmelse som i disse eksemplene viser, kan ha innvirkning på demotivasjon og frafall i Vg1 og Vg2 (Bruvik \& Haaland in-press; Bødtker-Lund et al., 2017). 


\section{Referanser}

Amble, N., Møller, E. \& Vagle, I. (2017). Feministisk aksjonsforskning i det yrkesfaglige feltet. I S. Gjøtterud, H. Hiim, D. Husebø, L. H. Jensen, T. H. Steen-Olsen, \& E. Stjernstrøm (Red.), Aksjonsforskning i Norge: Teoretisk og empirisk mangfold (s. 315-335). Oslo: Cappelen Damm Akademisk.

Biesta, G. J. J. (2014). Pragmatising the curriculum: Bringing knowledge back into the curriculum conversation, but via pragmatism. Curriculum Journal, 25(1), 29-49. doi: https://doi.org/10.1080/00220272.2013.798839.

Bruvik, Å, N. \& Haaland, G. (in press). Relevans i Norsk yrkesopplæring. Elevenes opplevelse av relevans gjennom første år i videregående skole. Nordyrk journal og vocation education and training.

Bødtker-Lund, D., Hansen, K. H., Haaland, G., \& Vagle, I., (2017). Endringsbehov i norsk yrkesopplæring? - Elevers, lærlingers og yrkesfaglæreres erfaringer med yrkesopplæring i Vg1. Skandinavisk tidsskrift for yrker og profesjoner i utvikling, 2, 1-33. doi: https://doi.org/10.7577/sjvd.2577

Creswell J.W. (2009). Qualitative inquiry \& research design: Choosing among five approaches. London: Sage Publications.

Dahlback, J., Hansen, K, Haaland, G., \& Sylte, A. L. (2011). Yrkesdidaktisk kunnskapsutvikling og implementering av nye laereplaner (KIP): Veien til yrkesrelevant opplaring fra første dag $i$ Vgl (Rapport og utredninger nr. 1/2001). Lillestrøm: Høgskolen i Akershus.

Dale, E. L. (2008). Uddannelse, Demokrati og videnskap: John Dewey. I C. Madsen, \& P. Maunch (Red.), Med Dewey in mente (s. 53-81). Århus: Klim.

Dewey, J. (1938). Democracy and Education: An introduction to the Philosophy of Education. New York: The Macmillan Company.

Dewey, J. (1966). Democracy and education: An introduction to the philosophy of education. New York: The Free Press. (1. utgivelse 1916).

Garmanslund, P. E., \& Witsø, H. (2017). Lærings- og arbeidsvaner hos lærlinger. Nordic Journal og Vocation Educational and Training, 7(1), 23-41. http://www.njvet.ep.liu.se/issues/2017/v7/i1/03/njvet_17v7i1a3.pdf

Giorgi, A. (1985). Phenomenology and Psychological Research: Essay. Pittsburgh, Pa: Duquesne University Press. 
Haaland, G. \& Nilsen, S. (2013). Laering gjennom praksis: Innhald og arbeidsmåter $i$ yrkesopplaringen: En grunnbok i yrkesdidaktikk. Oslo: PEDLEX norsk skoleinformasjon.

Halkier, B. (2010). Fokusgrupper (K. Gjerpe, Overs.). Oslo: Gyldendal akademisk.

Hartviksen, M. \& Kvers $\varnothing y$, K. S. (2008). Samarbeid og konflikt: To sider av samme sak: SØT-modellen. Bergen: Fagbokforl.

Hansen, K. H. \& Haaland, G. (2015). Utfordring i Norsk yrkesopplæring. I K. Hansen, T. L. Hoel \& G. Haaland (Red.), Tett på yrkesopplaring: Yrkesrelevant, tilpasset og samfunnstjenelig? (s. 19-49). Bergen: Fagbokforl.

Hiim, H. (2013). Praksisbasert yrkesutdanning: Hvordan utvikle relevant yrkesutdanning for elever og arbeidsliv? Oslo: Gyldendal akademisk.

Hovland, K. (2015). Helt fjern opplæring. I K. Hansen, T. L. Hoel \& G. Haaland (Red.), Tett på yrkesopplaering: Yrkesrelevant, tilpasset og samfunnstjenelig? (s. 212-229). Bergen: Fagbokforl.

Illeris, K. (2012). Laring (Y. Nordgård, Overs.). Oslo: Gyldendal akademisk.

Johannessen A., Tufte P. A., \& Kristoffersen L. (2016). Introduksjon til samfunnsvitenskapelig metode (4. utg.). Oslo: Abstrakt forl.

Keller, J. M. (2000). How to integrate learner motivation planning in lesson planning: The ARCS model approach. Paper presentert på VII Semanario, Santiago, Cuba. Hentet fra https://goo.gl/mD7w6D.

Keller, J. M. (2010). Motivational design for learning and performance: New York: Springer.

Kember, D., Ho, A., \& Hong, C. (2008). The Importance of Establishing Relevance in Motivating Student Learning, Active Learning in Higher Education, 9(3), 249-263. doi: https://doi.org/10.1177/1469787408095849

Kvale, S. (1996). InterViews: An introduction to Qualitative Research Interviewing. Thousand Oaks, Calif.: Sage.

Malterud, K. (2003). Kvalitative metoder i medisinsk forskning: En innføring (2. utg.). Oslo: Universitetsforl.

Malterud, K. (2011). Kvalitative metoder i medisinsk forskning: En innføring (3. utg.). Oslo: Universitetsforl.

Malterud, K. (2017). Kvalitative forskningsmetoder for medesin og helsefag (4. utg.). Oslo: Universitetsforl.

Meld. St. 20 (2012-2013). På rett vei: Kvalitet og mangfold i fellesskolen. Oslo:

Kunnskapsdepartementet. 
Meld. St. 22 (2010-2011). Motivasjon - Mestring - Muligheter: Ungdomstrinnet. Oslo: Kunnskapsdepartementet.

Meld. St. 28. (2015-2016). Fag - Fordypning - Forståelse: En fornyelse av Kunnskapslфftet. Oslo: Kunnskapsdepartementet.

Møller, J. \& Sundli, L. (Red.). (2007). Laringsplakaten: Skolens samfunnskontrakt. Kristiansand: Høyskoleforl.

NOU 2015:8. (2015). Fremtidens skole. Oslo: Kunnskapsdepartementet.

Opplæringslova. (1998). Lov om grunnskolen og den vidaregåande opplaeringa. Hentet fra https://lovdata.no/lov/1998-07-17-61

Reason, P. \& Bradbury, H. (2001). Introduction. I P. Reason \& H. Bradbury (Red.), Handbook of Action Research: Participative inquiry and practice (s. 1-15). London: Sage.

St.meld. nr. 16 (2006-2007). ... og ingen sto igjen: Tidlig innsats for livslang laering. Oslo: Kunnskapsdepartementet.

St.meld. nr. 30 (2003-2004). Kultur for laring. Oslo: Kunnskapsdepartementet.

Sylte, A.L. (2015). Yrkesretting av teorien og yrkesdifferensiering - en vei for å hindre frafall i yrkesopplæringen i videregående skole. I O. Eikeland, H. Hiim \& E. Schwencke (Red.), Yrkespedagogiske perspektiver (s.140 - 162). Oslo: Gyldendal Akademiske.

Sylte, A. L. (2016). Profesjonspedagogikk - profesjonsretting/yrkesretting av pedagogikk og didaktikk (2. utg.). Oslo: Gyldendal akademisk.

Sylte, A. L. \& Jahanlu, D. (2017). Profesjonsrettet lærerutdanning for yrkesfag - dagens undervisning og opplevelse av relevans. Scandinavian journal of vocations in development, 2, 1-36. doi: https://doi.org/10.7577/sjvd.2010

Utdanningsdirektoratet. (2015, 25. august). Prinsipper for opplaringen (LK06). Hentet fra. https://www.udir.no/laring-og-trivsel/lareplanverket/prinsipper-for-opplaringen2/

Utdanningsdirektoratet. (2015, 25. august). Den generelle dek av læreplanen (LK06). Hentet fra. https://www.udir.no/laring-og-trivsel/lareplanverket/generell-del-av-lareplanen/

Vaage, S. (2010). Utdanning til demokrati. Oslo: Abstrakt forl. 